\title{
PRINGIPLES OF
}

PLANT PATHOLOGY 


\section{PRINGIPLES OF \\ PLANT PATHOLOGY}

S. A. J. TARR, Ph. D., D. Sc.

Reader in Plant Pathology, The Department of Biological Sciences, University of Exeter 
(C) S. A. J. Tarr 1972

Softcover reprint of the hardcover 1st edition 1972

All rights reserved. No part of this publication may be reproduced or transmitted, in any form or by any means, without permission

First published 1972

Published by

THE MAGMILLAN PRESS

London and Basingstoke

Associated companies in New York, Toronto

Melbourne, Dublin, Johannesburg and Madras

ISBN 978-1-349-00357-0 ISBN 978-1-349-00355-6 (eBook)

DOI 10.1007/978-1-349-00355-6 


\section{Contents}

Chapter 1. Introduction: general concepts 1

2. Historical introduction to plant pathology 8

3. The causes of plant diseases: non-parasitic agents 18

4. Viruses and Mycoplasma-like organisms as plant pathogens 42

5. Plant diseases caused by parasites: the taxonomy of plant pathogens $\quad 79$

6. Bacteria as plant pathogens 87

7. Angiosperms, algae and Protozoa as plant pathogens 103

8. Root diseases 112

9. Plant injury due to insects, mites, nematodes and other pests

126

10. The entry of pathogens into plants 138

11. The colonization of the infected plant 170

12. The results of infection 193

13. Mechanisms of attack 216

14. Mechanisms of defence 247

15. The genetics of plant-pathogen interaction 286

16. The factors which influence infection 307

17. Epidemiology: the seasonal carry-over of plant pathogens 329

18. The dispersal of plant pathogens 351

19. The spread of pathogens within crop areas; epiphytotics 379

20. The factors which influence the spread of pathogens within crop areas 399

21. The forecasting of plant diseases 416

22. The assessment of disease incidence and crop loss 430

23. The control of plant diseases: general considerations 455

24. Disease control by plant sanitation 469

25. Disease control by cultural practices 478

26. Physical and chemical methods of disease control (1) 490

27. Physical and chemical methods of disease control (2) 510

28. Disease control by plant breeding and selection 544

29. Disease control by legislation and international cooperation: research and education $\quad 558$

30. Sources of information $\quad 569$

References $\quad 580$

Acknowledgements 624

Index $\quad 625$ 


\section{Preface}

This book is an attempt to provide a reasonably comprehensive account of plant pathology for students wishing to specialize in the subject, and for those other students who wish to obtain a background of plant pathology. The emphasis throughout is on principles, with references to sources of more detailed information where necessary. Since plant diseases caused by fungi have been more intensively studied than those due to any other single cause, the subject is discussed mainly with reference to fungal plant pathogens but reference is made to other groups of plant pathogens where appropriate. Although viruses cause many important plant diseases a detailed treatment of this group is precluded by limitations of space; fortunately several excellent books on plant viruses have been published in recent years.

Different plant pathologists have different ideas as to the form a book on plant pathology should take. After considerable thought I have adopted a fairly conventional plan in which two introductory chapters are followed by chapters on the main causes of disease in plants, the interaction of plant and pathogen, the interaction of populations of plants and pathogens as influenced by the environment, and the control of plant diseases. A brief chapter on plant injury due to insects, nematodes, mites and other animals has been included because, in my view, a wider approach to plant damage whether due to pathogens, pests or non-parasitic agents is desirable. The book ends with a chapter on sources of information on plant diseases. It would be unrealistic to suppose that the text is free from errors and notification of any errors or omissions will be appreciated.

I should like to thank Dr G. G. Ainsworth for contributing Chapter 2, Professor S. D. Garrett, FRS for checking Chapter 8, Mr H. G. Morgan (Chapter 9), Dr G. G. Pritchard (Chapter 3) and Miss S. M. Robb (Chapter 4). My thanks are also due to the authors and publishers who have allowed me to reproduce figures and tables from books and published papers, as acknowledged. I am greatly indebted to Miss M. A. Turner who took many of the original photographs, and to Dr J. E. Crosse (Figs. 6.2, 6.3, 6.4), Miss S. M. Robb (Fig. 4.7), Mr P. S. Rattan (Figs. 17.2, 26.2) and Professor J. Webster (Fig. 17.3) who very kindly allowed me to use photographs in their possession.

$\begin{array}{lr}\text { The Hatherly Biological Laboratories } & \text { S. A. J. TARR } \\ \text { University of Exeter } & \text { May } 1972 \\ \text { Devonshire } & \end{array}$


To N.P.T. and G.P.T. 